\title{
Researches Regarding Weed Control in Soybean Crop
}

\author{
Teodor RUSU ${ }^{1 *}$, Cornel CHEȚAN ${ }^{2}$, Ileana BOGDAN ${ }^{1}$, Felicia CHEȚAN ${ }^{2}$, \\ Mircea IGNEA ${ }^{2}$, Bogdan DUDA ${ }^{1}$, Ilarie IVAN ${ }^{3}$ \\ ${ }^{1}$ University of Agricultural Sciences and Veterinary Medicine Cluj-Napoca, 3-5 Manastur Street, \\ 400372, Cluj-Napoca, Romania; E-mail: \\ ${ }^{2}$ Agricultural Research and Development Station from Turda, 27 Agriculturii Street, 401100, Turda, Ro- \\ mania; \\ ${ }^{3}$ Technical University of Cluj, B-dul Muncii, 103-105, 400641, Cluj-Napoca, Romania \\ * corresponding author: trusu@usamvcluj.ro
}

Bulletin USAMV series Agriculture 71(2)/2014

Print ISSN 1843-5246; Electronic ISSN 1843-5386

DOI 10.15835/buasvmcn-agr: 10257

\begin{abstract}
Soybean shows special sensitivity to weeding while in the early growth stages until the land is covered, but also in the mature stages after the leaves begin to fall. Once invaded by weeds, especially in the first phase of growth, the culture is no longer recovering even if later, weeds are controlled. The purpose of presented paper is to identify an integrated weed control system for the soybean crop, starting from: (i) requirements of the soybean crop towards environmental and technological factors so that it can effectively compete with weeds; (ii) reporting the weed control strategy to new climatic conditions through specific measures of adaptation; (iii) strategies research of chemical complementary herbicides regarding their combat range and time of application. In order to maintain soybean cultures clean of weeds, it is necessary, in general, to apply two chemical treatments, the first ppi/pre-emergent spraying for some annual dicotyledonous and monocotyledonous weeds and the 2nd post-emergence treatment for dicotyledonous weeds. If on vegetation exists infestations both with annual or perennial monocotyledonous weeds, good results are obtained by associating two complementary herbicides, which combat both monocotyledonous and dicotyledonous weeds. The lowest degree of weed (7.5 weed $/ \mathrm{m}^{2}$ ) was determined with the combination: Frontier Forte \& Surdone \& Pulsar \& Stratos Ultra.
\end{abstract}

Keywords: weed control, chemical strategies, soybean.

\section{INTRODUCTION}

Soybean is one of the most famous and valuable agricultural plants, being useful for human consumption, animal nutrition and industry (Muntean et al., 1995; Duda et al., 2008). Soybean being a legume, contributes substantially to increasing the fertility of the soil, but can also be the main feedstock for bio-diesel (USA and Brazil). Thermal resources constitute one of the main limiting factors in expanding this culture in the northern areas, while in the southern, the efficiency of the culture is conditioned as a rule, by water resources (Rusu, 2001; Domuta et al., 2012; Moraru and Rusu, 2013; Roman, 2013). Soy shows special sensitivity to weeding while in the early growth stages until the land is covered, but also in the mature stages after the leaves begin to fall. Once invaded by weeds, especially in the first phase of growth, the culture is no longer recovering even if later, weeds are controlled. Soy being a plant with small-middle size is part of a group of agricultural plants easily competed by weeds, thus resulting in large production losses (30-80\%), sometimes compromising the whole culture. (Berca, 2004; Avola et al., 2008). The most common encountered weeds in soybeans are in particular those with late spring germination, but not exclusively (Sartorato et al., 1996; Gus et al., 2004; Rusu et al., 2012): Echinochloa crusgalli, Setaria sp., Digitaria sanguinalis, Sorghum 
halepense, Agropyron repens, Solanum nigrum, Amaranthus retroflexus, Chenopodium album, Galinsoga parviflora, Xanthium sp., Abutilon teophrasti, Datura stramonium, Polygonum sp., Cirsium arvense, Convolvulus arvensis etc.

Explosive weeding in the soybean crop (due to late spring sowing when all vegetation revives explosively) extremely diversifies infestation and ratio variability of weed species and requires a specific strategy of integrated weed control, based on reducing their number below the economic threshold of pest. Climate warming of the past few years, require specific measures of adapting this strategy, especially of technological nature, for the soybean crop. Thus, the amount of biologically active degrees registered for soybeans, in the monitoring period 2008-2012 in the Transylvanian Plain, ranges between $1044-1568^{\circ} \mathrm{C}\left(\mathrm{T}>8^{\circ} \mathrm{C}, 150\right.$ days), placing the soybean in the II, III and IV culture zones (Weindorf et al., 2009; Rusu et al., 2014). Thus, varieties with extended period of vegetation can be grown, more productive, but in the same period, $38.9 \%$ of the vegetation period, the humidity recorded is below the optimal moisture range. Meanwhile, as the habitat is degraded due to climate change, plant species that will survive are those with a short life cycle, which can adapt and spread more easily. These changes have led to the invasion of specific weed species such as Xanthium sp. Seeds of the species germinate at elevated temperatures of $20-30^{\circ} \mathrm{C}$, at a depth of $2-10 \mathrm{~cm}$. Germination is staggered, depending on the temperature, humidity of the ground and the depth of the embedding. The first time germinates the seed from lower achenes, while seeds from higher achenes germinate only when the first one was destroyed by tillage, hoeing or herbicides. In these circumstances, the most important aspect of the applied technology is to conserve water in soil through minimum tillage or direct seeding, providing mulch on the soil's surface and preventive control of weeds. Sufficient moisture in the soil is the main condition for obtaining good results.

The purpose of presented paper is to identify an integrated weed control system for the soybean crop, starting from: (1) requirements of the soybean crop towards environmental and technological factors so that it can effectively compete with weeds; (2) reporting the weed control strategy to new climatic conditions through specific measures of adaptation; (3) strategies research of chemical complementary herbicides regarding their combat range and time of application.

\section{MATERIALS AND METHODS}

Research was conducted in the agricultural year of 2013-2014 at SCDA Turda, located in the physical-geographical area of Transylvanian Plain on a vertic faeoziom soil type with clay-loamy texture, neutral ph, good and very good supply of mobile phosphorus and potassium, soil's humus content being average.

As mono-factorial experience, is organized within the demonstrative Donau Soja Platform, following the placed end to end blocks method (storied). As biological material was used Felix soybean variety (group of maturity 00 , vegetation period 122 days) created by Agricultural Research and Development Station, Turda (SCDA Turda). It is a variety with high waist suitable to mechanical harvesting with basal pods insertion height of 16 $\mathrm{cm}$ and a good resistance to pests and diseases.

Experimental variants are:

$\mathrm{V}_{1}$ - Frontier Forte (dimetenamid-P $720 \mathrm{~g} / \mathrm{l}$ ) $1.4 \mathrm{l} / \mathrm{ha}+$ Surdone (metribuzin $700 \mathrm{~g} / \mathrm{kg}$ ) 0.4 $\mathrm{kg} / \mathrm{ha}$ (+ Trend $250 \mathrm{ml} / \mathrm{ha}$ ) preem + Pulsar 40 (imazamox $40 \mathrm{~g} / \mathrm{l}$ ) $1 \mathrm{l} / \mathrm{ha}$ postem early + Stratos Ultra (cicloxidim $100 \mathrm{~g} / \mathrm{l}) 3 \mathrm{l} /$ ha postem;

$\mathrm{V}_{2}$ - Stomp 330 EC (pendimetalin $330 \mathrm{~g} / \mathrm{l}$ ) $5 \mathrm{l} / \mathrm{ha}+$ Surdone (metribuzin $700 \mathrm{~g} / \mathrm{kg}$ ) $0.4 \mathrm{~kg} /$ ha (+ Trend $250 \mathrm{ml} / \mathrm{ha}$ ) preem + Basagran Forte (bentazon $480 \mathrm{~g} / \mathrm{l}+$ wettol $150 \mathrm{~g} / \mathrm{l}$ ) $2 \mathrm{l} / \mathrm{ha}+$ Agil 100 EC (propaquizafop $100 \mathrm{~g} / \mathrm{l}$ ) $0.8 \mathrm{l} / \mathrm{ha}$ postem (tank-mix);

$\mathrm{V}_{3}$ - Surdone (metribuzin $700 \mathrm{~g} / \mathrm{kg}$ ) $0.5 \mathrm{~kg} /$ ha (+ Trend $250 \mathrm{ml} / \mathrm{ha}$ ) preem + Harmony $50 \mathrm{SG}$ (tifensulfuron-metil 50\%) $12 \mathrm{~g} / \mathrm{l}+$ Leopard 5 EC (quizalofop-P-etil $50 \mathrm{~g} / \mathrm{l}$ ) $0.7 \mathrm{l} / \mathrm{ha}$ postem (tankmix);

$\mathrm{V}_{4}$ - Dual Gold 960 EC (S-metolaclor $\left.960 \mathrm{~g} / \mathrm{l}\right)$ $1 \mathrm{l} / \mathrm{ha}+$ Pledge $50 \mathrm{WP}$ (flumioxazin 50\%) $90 \mathrm{~g} / \mathrm{ha}$ preem + Basagran Forte (bentazon $480 \mathrm{~g} / \mathrm{l}+$ wettol $150 \mathrm{~g} / \mathrm{l}$ ) $2 \mathrm{l} / \mathrm{ha}+$ Leopard 5 EC (quizalofop-P-etil $50 \mathrm{~g} / \mathrm{l}$ ) $0.7 \mathrm{l} /$ ha postem (tank-mix).

Size of experimental plots is $100 \mathrm{~m}^{2}$, distance between rows is $12.5 \mathrm{~cm}$, width of the sole for the herbicided variant is $6 \mathrm{~m}$, lot width of $24 \mathrm{~m}$, lot length of $50 \mathrm{~m}$, area of a variant with 3 repetitions is $300 \mathrm{~m}^{2}$ and the lot area of $1,200 \mathrm{~m}^{2}$. The previous plant for the soybean crop was maize. Determining 
Tab. 1. List of homologated herbicides for application in soybean crop

\begin{tabular}{|c|c|c|c|c|c|c|}
\hline $\begin{array}{l}\text { No. } \\
\text { item }\end{array}$ & $\begin{array}{l}\text { HERBICIDE } \\
\text { (commercial } \\
\text { product) }\end{array}$ & $\begin{array}{l}\text { The content of } \\
\text { herbicide's active } \\
\text { compounds }\end{array}$ & Combated weeds & Application phases & $\begin{array}{l}\text { The dose of } \\
\text { commercial } \\
\text { product }\end{array}$ & $\begin{array}{l}\text { G. } \\
\mathrm{T} .\end{array}$ \\
\hline 0 & 1 & 2 & 3 & 4 & 5 & 6 \\
\hline \multicolumn{7}{|c|}{ A. Herbicide treatments applied ppi/pre-emergent } \\
\hline 1 & $\begin{array}{l}\text { ACETOCLOR } \\
\text { SUPER }\end{array}$ & $\begin{array}{c}\text { acetoclor } 840 \mathrm{~g} / \mathrm{l}+ \\
\text { antidot }\end{array}$ & $\begin{array}{l}\text { Monocotyledonous and some dicotyledonous } \\
\text { weeds }\end{array}$ & $\begin{array}{l}\text { ppi / pre- } \\
\text { emergent }\end{array}$ & $1.75-2.5 \mathrm{l} / \mathrm{ha}$ & $\mathrm{Xi}$ \\
\hline 2 & GUARDIAN & acetoclor $820 \mathrm{~g} / \mathrm{l}$ & $\begin{array}{l}\text { Annual monocotyledonous weeds Setaria, } \\
\text { Echinochloa, Digitaria }\end{array}$ & $\begin{array}{l}\text { ppi / pre- } \\
\text { emergent }\end{array}$ & $1.75-2.5$ /ha & $\mathrm{Xi}$ \\
\hline 3 & RELAY & acetoclor $900 \mathrm{~g} / \mathrm{l}$ & $\begin{array}{l}\text { Annual monocotyledonous and } \\
\text { dicotyledonous weeds }\end{array}$ & $\begin{array}{l}\text { ppi / pre- } \\
\text { emergent }\end{array}$ & $1.7-2.2 \mathrm{l} / \mathrm{ha}$ & $\mathrm{Xi}$ \\
\hline 4 & TORPEDO 90EC & acetoclor $900 \mathrm{~g} / \mathrm{l}$ & Annual monocotyledonous weeds & $\begin{array}{l}\text { ppi / pre- } \\
\text { emergent }\end{array}$ & $1.7-2.2 \mathrm{l} / \mathrm{ha}$ & $\mathrm{Xn}$ \\
\hline 5 & TROPHY SUPER & acetoclor $840 \mathrm{~g} / \mathrm{l}$ & $\begin{array}{l}\text { Annual monocotyledonous weeds } \\
\text { Echinochloa, Setaria, Digitaria, }\end{array}$ & $\begin{array}{l}\text { ppi / pre- } \\
\text { emergent }\end{array}$ & $1.8-2.4 \mathrm{l} / \mathrm{ha}$ & $\mathrm{Xi}$ \\
\hline 6 & $\begin{array}{l}\text { DUAL GOLD } \\
960 \mathrm{EC}\end{array}$ & S-metolaclor $960 \mathrm{~g} / \mathrm{l}$ & $\begin{array}{l}\text { Monocotyledonous and some dicotyledonous } \\
\text { weeds (not together with Pledge) }\end{array}$ & $\begin{array}{l}\text { ppi / pre- } \\
\text { emergent }\end{array}$ & $1.0-1.5 \mathrm{l} / \mathrm{ha}$ & $\mathrm{Xi}$ \\
\hline 7 & FRONTIER FORTE & dimetenamid $720 \mathrm{~g} / \mathrm{l}$ & $\begin{array}{l}\text { Annual monocotyledonous and some } \\
\text { dicotyledonous weeds }\end{array}$ & $\begin{array}{l}\text { ppi / pre- } \\
\text { emergent }\end{array}$ & $0.8-1.4 \mathrm{l} / \mathrm{ha}$ & $\mathrm{Xn}$ \\
\hline 8 & PROPONIT 720EC & propisoclor $720 \mathrm{~g} / \mathrm{l}$ & $\begin{array}{l}\text { Annual monocotyledonous and some } \\
\text { dicotyledonous weeds }\end{array}$ & $\begin{array}{l}\text { ppi / pre- } \\
\text { emergent }\end{array}$ & $2-3 \mathrm{l} / \mathrm{ha}$ & $\mathrm{Xi}$ \\
\hline 9 & STOMP 330EC & pendimetalin $330 \mathrm{~g} / \mathrm{l}$ & $\begin{array}{l}\text { Annual monocotyledonous and some partial } \\
\text { dicotyledonous weeds }\end{array}$ & $\begin{array}{l}\text { ppi / pre- } \\
\text { emergent }\end{array}$ & 4-5 l/ha & $\mathrm{Xn}$ \\
\hline 10 & SURDONE & metribuzin $700 \mathrm{~g} / \mathrm{kg}$ & $\begin{array}{l}\text { Annual monocotyledonous and some } \\
\text { dicotyledonous weeds }\end{array}$ & pre-emergent & $0.25-0.5 \mathrm{~kg} / \mathrm{ha}$ & $\mathrm{Xn}$ \\
\hline 11 & PLEDGE 50WP & flumioxazin 50\% & $\begin{array}{l}\text { Annual dicotyledonous weeds (residual } \\
\text { pellicular) }\end{array}$ & pre-emergent & $90 \mathrm{~g} / \mathrm{ha}$ & $\mathrm{Xi}$ \\
\hline \multicolumn{7}{|c|}{ B. Herbicide treatments applied postemergence } \\
\hline 12 & AGIL 100EC & $\begin{array}{c}\text { propaquizafop } \\
100 \mathrm{~g} / \mathrm{l}\end{array}$ & Annual monocotyledonous weeds, Sorghum & post-emergent & $0.8-1.5 \mathrm{l} / \mathrm{ha}$ & $\mathrm{Xi}$ \\
\hline 13 & ANACONDA & $\begin{array}{l}\text { quizalofop-p-etil } \\
50 \mathrm{~g} / \mathrm{l} \\
\end{array}$ & Sorghum from rhizomes & post-emergent & $1.5-2 \mathrm{l} / \mathrm{ha}$ & $\mathrm{Xn}$ \\
\hline 14 & ARAMO 50EC & tepraloxidim $50 \mathrm{~g} / \mathrm{l}$ & Annual monocotyledonous weeds, Sorghum & post-emergent & $1-2 \mathrm{l} / \mathrm{ha}$ & $\mathrm{Xn}$ \\
\hline 15 & ELEGANT 05EC & $\begin{array}{l}\text { quizalofop-p-etil } \\
50 \mathrm{~g} / \mathrm{l} \\
\end{array}$ & $\begin{array}{l}\text { Annual monocotyledonous weeds Setaria, } \\
\text { Echinochloua, Sorghum from seeds }\end{array}$ & post-emergent & $0.75 \mathrm{l} / \mathrm{ha}$ & $\mathrm{Xn}$ \\
\hline 16 & FOCUS ULTRA & cicloxidim $100 \mathrm{~g} / \mathrm{l}$ & Sorghum from rhizomes & post-emergent & $3-4$ l/ha & $\mathrm{Xn}$ \\
\hline 17 & $\begin{array}{l}\text { FURORE SUPER } \\
75 \mathrm{EW}\end{array}$ & $\begin{array}{l}\text { fenoxaprop-P-etil } \\
75 \mathrm{~g} / \mathrm{l} \\
\end{array}$ & Sorghum from rhizomes & post-emergent & $3.5 \mathrm{l} / \mathrm{ha}$ & $\mathrm{Xi}$ \\
\hline 18 & $\begin{array}{l}\text { KILLER SUPER } \\
\text { 5EC } \\
\end{array}$ & $\begin{array}{l}\text { quizalofop-P-etil } \\
50 \mathrm{~g} / \mathrm{l}\end{array}$ & Annual monocotyledonous weeds, Sorghum & post-emergent & $0.75-2$ l/ha & $\mathrm{Xi}$ \\
\hline 19 & LEOPARD 5EC & $\begin{array}{l}\text { quizalofop-P-etil } \\
50 \mathrm{~g} / 1 \\
\end{array}$ & Annual monocotyledonous weeds, Sorghum & post-emergent & $0.7-2 \mathrm{l} / \mathrm{ha}$ & $\mathrm{Xi}$ \\
\hline 20 & PANTERA 40EC & $\begin{array}{l}\text { quizalofop-P-etil } \\
40 \mathrm{~g} / \mathrm{l}\end{array}$ & Annual monocotyledonous weeds, Sorghum & post-emergent & $0.75-2 \mathrm{l} / \mathrm{ha}$ & $\mathrm{Xn}$ \\
\hline 21 & SELECT SUPER & cletodim $120 \mathrm{~g} / \mathrm{l}$ & Annual monocotyledonous weeds, Sorghum & post-emergent & $0.6-2 \mathrm{l} / \mathrm{ha}$ & $\mathrm{Xi}$ \\
\hline 22 & TARGA SUPER & $\begin{array}{l}\text { quizalofop-P-etil } \\
50 \mathrm{~g} / 1\end{array}$ & Annual monocotyledonous weeds, Sorghum & post-emergent & $1-2.5 \mathrm{l} / \mathrm{ha}$ & $\mathrm{Xi}$ \\
\hline 23 & TIGER P & $\begin{array}{l}\text { fluazifop-P-butil } \\
150 \mathrm{~g} / \mathrm{l}\end{array}$ & $\begin{array}{c}\text { Annual monocotyledonous weeds, Setaria, } \\
\text { Echinochloa, Digitaria, Sorghum }\end{array}$ & post-emergent & $0.8-1.3 \mathrm{l} / \mathrm{ha}$ & $\mathrm{Xi}$ \\
\hline 24 & PULSAR 40SL & Imazamox 40g/l & $\begin{array}{c}\text { Annual monocotyledonous and dicotyledonous } \\
\text { weeds (indcluding Abutilon, Solanum, } \\
\text { Xantium, Datura) }\end{array}$ & early post-emergent & $0.75-1 \mathrm{l} / \mathrm{ha}$ & $\mathrm{Xi}$ \\
\hline 25 & HARMONY 50SG & $\begin{array}{l}\text { tifensulfuron-metil } \\
50 \% \\
\end{array}$ & $\begin{array}{l}\text { Annual dicotyledonous weeds (excluding } \\
\text { Solanum and Datura) }\end{array}$ & post-emergent & $\begin{array}{l}12 \mathrm{~g} / \mathrm{ha}+0.1 \% \\
\text { Trend }\end{array}$ & $\mathrm{Xi}$ \\
\hline 26 & BASAGRAN FORTE & $\begin{array}{c}\text { bentazon } 480 \mathrm{~g} / \mathrm{l} \\
\text { wettol } 150 \mathrm{~g} / \mathrm{l}\end{array}$ & $\begin{array}{l}\text { Annual and perennial dicotyledonous weeds } \\
\text { (Convolvulus, Cirsium) }\end{array}$ & post-emergent & $2-2.5 \mathrm{l} / \mathrm{ha}$ & $\mathrm{Xi}$ \\
\hline
\end{tabular}


the degree of weeding was done with the metric frame using the numerical method.

\section{RESULTS AND DISCUSSIONS}

The recommended strategy for the control of weeds in soybean culture contains the following:

1. Planning an integrated system for weed control in crop rotations of 4-5 years. Introducing soybean crop in rotation with straw cereals and maize is very important, given that perennial dicotyledonous weeds (Cirsium, Sonchus, Convolvulus, Lathyrus etc.) are very difficult to control in the soybean culture, while herbicides applied to maize and straw cereals control them, and in addition to that, can obviously reduce the overall weeding of the field.

2. Improving the management of plant cultivation and reintroduction of "better agrotechnical practices". Positioning the cultures after preceding ones that leave the ground clear of weeds, crop rotation and herbicides, correct soil tillage, control of weeds that arise primarily at seedbed preparation and choosing the optimal sowing period, contributes to a significant extent to the reduction of weed infestation in the soybean crop.

3 . The use of the herbicides based on glyphosate (Roundup, Dominator, Cosmic, Clinic, Sikosto, Sanglypho, Glyfos, Glifotim etc.), applied before, during or after sowing, but before the sprung of the soybean plants, at a dosage of 3-4 (5) l/ha. Not less than 4 years the sprayed soles will be free of perennial weeds, until a new re-infestation. It is recommended that these herbicides to be applied after rain or in the evening (when leaves are turgid) and not during extreme heat. To fully absorb and translocate in the underground parts is required that after application, 5-6 hours, it does not rain. Since the glyphosate is absorbed only by the leaves, the one that reaches the ground is lost therefore it must be applied by spraying weeds with as small amounts of water as possible. With conventional sprayer devices can be applied the recommended doses in 100-150 l/ha. It can be associated tank-mix $2.4 \mathrm{D}-0.5 \mathrm{l} / \mathrm{ha}$ (7 days) with $1 \mathrm{l} /$ ha (30 days before the sowing of the soybean crop), in order to increase the efficiency of the dicotyledonous weed control. For the control of residual weeds, tank-mix may be associated with Surdone or Pledge 50WP.

4. Application of herbicides according to the weed spectrum, at optimal doses and time periods. In order to maintain soybean cultures clean of weeds, it is necessary, in general, to apply two chemical treatments, the first ppi/pre-emergent spraying for some annual dicotyledonous and monocotyledonous weeds (point A in Table 1) and the 2nd post-emergence treatment for dicotyledonous weeds. If on vegetation exists infestations

Tab. 2. Influence of herbicide variant on the weed growth of culture soybean in flowering phase

\begin{tabular}{|c|c|c|c|c|}
\hline \multirow[b]{2}{*}{ Weeds } & \multicolumn{4}{|c|}{ No. weeds $/ \mathrm{m}^{2}$} \\
\hline & $\begin{array}{l}\mathrm{V}_{1}-\text { Frontier Forte } \\
\text { \& Surdone \& Pulsar } \\
\text { \& Stratos Ultra }\end{array}$ & $\begin{array}{c}\mathrm{V}_{2}-\text { Stomp } \\
\text { \& Surdone \& } \\
\text { Basagran Forte \& } \\
\text { Agil }\end{array}$ & $\begin{array}{l}\mathrm{V}_{3}-\text { Surdone } \\
\text { \& Harmony \& } \\
\text { Leopard }\end{array}$ & $\begin{array}{c}\mathrm{V}_{4}-\text { Dual Gold } \\
\text { \& Pledge \& } \\
\text { Basagran Forte \& } \\
\text { Leopard }\end{array}$ \\
\hline Echinochloa crus-galli & - & - & 4.1 & 3.2 \\
\hline Setaria glauca & - & 1.2 & 3.1 & 2.1 \\
\hline Chenopodium album & - & 2.1 & 2.2 & 1.1 \\
\hline Hibiscus trionum & 2.2 & 1.1 & 2.5 & - \\
\hline Xanthium strumarium & - & - & 1.2 & - \\
\hline Euphorbia helioscopia & - & 1.2 & - & - \\
\hline Convolvulus arvensis & 2.2 & 3.1 & 2.1 & 3.1 \\
\hline Cirsium arvense & - & 3.2 & - & - \\
\hline Lathyrus tuberosus & 3.1 & 4.1 & 2.1 & 3.1 \\
\hline Total & 7.5 & 16 & 17.3 & 12.6 \\
\hline Soybean plant height, $\mathrm{cm}$ & 34 & 38 & 36 & 39 \\
\hline $\begin{array}{l}\text { Density of the soybean, } \\
\text { plants } / \mathrm{m}^{2}\end{array}$ & 90 & 84 & 97 & 89 \\
\hline
\end{tabular}


both with annual or perennial monocotyledonous weeds, good results are obtained by associating two complementary herbicides, which combat both monocotyledonous and dicotyledonous weeds (point B in Table 1). Depending on the range of weed-infested crop of soybean, may be applied the homologated herbicides shown in Table 1.

The experimental variants were significantly reduced weeding soybean crop. During blossoming culture of soybean $(16 / 06 / 2014)$ culture was at a normal density and height (Table 2). The lowest degree of weed, only 7.5 weed $/ \mathrm{m}^{2}$, was determined in $V_{1}$-Frontier Forte \& Surdone \& Pulsar \& Stratos Ultra.

\section{CONCLUSION}

Application of ppi or pre-emergent herbicides is conditioned by the conditions of humidity. Thus, while drought conditions is recommended their incorporation at 2-4 cm depth before sowing, and while sufficient humidity conditions they should be applied pre-emergent at 1-2 days after sowing.

Treatments shall be made on vegetation when the soybean plants have 2-3 pairs of three folioled leaves and dicotyledonous weeds are at a maximum of 3 to 4 leaf stage. Monocotyledonous weed control treatments will be done in the phase of 2-3 leaflets until the twinning (especially Echinochloa). In general, if the maximum weed infestation is passed and the optimal phase is surpassed (of 4 leaflets), the application of maximum approved dose is recommended. Taking into account the gradual emergence of the weeds (especially Xanthium), treatments can be done sequentially, in two stages but in lower doses then when only for a single application treatment. Also, to increase the spectrum of control it can be applied concomitant treatments (tank-mix): Basagran Forte + Select Super $(2+0.6)$. Targa Super must not be applied together with Basagran. During post-emergence application of treatments is contraindicated to use mechanical or manual hoeing one week before treatment and two weeks after the treatment, in order not to interrupt the translocation of the herbicide.

Weed control in soybean crop ensures and enhances the return on investment for the used technology elements: fertilization, genetic potential of varieties, irrigation and exploitation of environmental resources.
Acknowledgments. This paper was published through the Partnership in priority domains - PNII, developed with the support of MEN-UEFISCDI, project no. PN-II-PT-PCCA-2013-4-0015.

\section{REFERENCES}

1. Avola, G., R. Tuttobene, F. Gresta, V. Abbate (2008). Weed control strategies for grain legumes. Agron. Sustain. Dev. No. 28: 389-395.

2. Berca, M. (2004). Integrated weed management. Ed. Ceres, Bucharest, p. 277.

3. Domuta, C., M. Sandor, Gh. Ciobanu, A. Samuel, C. Ciobanu, A. Domuta, C. Borza, Cr. Domuta, R. Brejea, M. Gatea (2012). Influence of the crop system on soil erosion and on the soil physical properties under the Romanian north-western area conditions. Journal of Environmental Protection and Ecology 13 (2): 736-745.

4. Duda, M., A. Fitiu, S. Mignon (2008). Field crops in organic farming. Ed. AcademicPress Cluj-Napoca.

5. Guş, P., S. Cernea, T. Rusu, I. Bogdan (2004). Systems of sowing, fertilization and crop management. Ed. Risoprint, Cluj-Napoca, p. 220.

6. Moraru, P. I., T. Rusu (2013). Effect of Different Tillage Systems on Soil Properties and Production on Wheat, Maize and Soybean Crop. World Academy of Science, Engineering and Technology, Paris, France, Issue 83: 162165.

7. Muntean, L.S., M. Axinte, I. Borcean, Gh. Roman (1995). Phytotechnics, EDP, Bucharest.

8. Roman, Gh. V. (2013). Soybean crop in the research \& development and eduction \& training systems in Romania. $2^{\text {nd }}$ International Danube Soya Congress Danube Soya and the European Protein Debate, Augsburg, 25-26 November 2013.

9. Rusu, T. (2001). The influence of Minimum Soil Tillage upon the soil, yield and efficiency. PhD Thesis, University of Agricultural Sciences and Veterinary Medicine of ClujNapoca.

10. Rusu, T., I. Bogdan, A. I. Pop (2012). Practical work tutorial in Agrotechnics. Ed. Grinta, Cluj-Napoca.

11. Rusu, T., P. I. Moraru, C. L. Coste, H. Cacovean, F. Chețan, C. Chețan (2014). Impact of climate change on climatic indicators in Transylvanian Plain, Romania. Journal of Food, Agriculture \& Environment Vol. 12 (1): 469-473.

12. Sartorato, I., A. Berti, G. Zanin (1996). Estimation of economic thresholds for weed control in soybean (Glycine max (L) Merr. Crop Protection vol. 15 (1): 63-68.

13. Weindorf, D., B. Haggard, T. Rusu, H. Cacovean, S. Jonson (2009). Soil Temperatures of the Transylvanian Plain, Romania. Buletin of University of Agricultural Sciences and Veterinary Medicine Cluj-Napoca, Agriculture, vol. 66 (1): 237-242. 